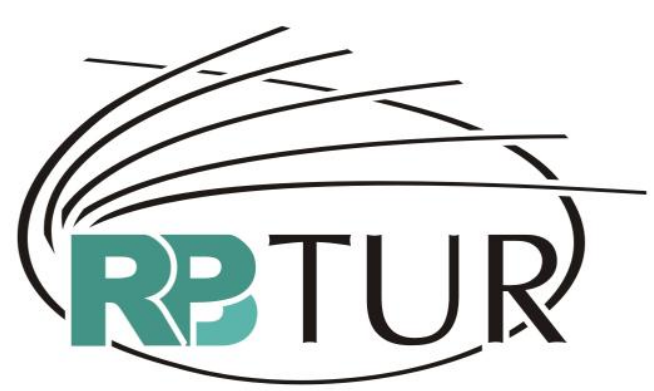

REVISTA BRASILEIRA DE PESQUISA EM TURISMO

\title{
A GESTÃO DO DESENVOLVIMENTO ECONÔMICO CONFLITANDO COM O PATRIMÔNIO NATURAL E CULTURAL DE SÃO SEBASTIÃO - SP
}

\author{
ECONOMIC GROWTH MANAGEMENT AND NATURAL AND \\ CULTURAL HERITAGE. CONFLICTS IN SÃO SEBASTIÃO, SP, \\ BRAZIL
}

LA GESTIÓN DEL DESARROLLO ECONÓMICO Y EL CONFLICTO CON EL PATRIMONIO NATURAL Y CULTURAL DE SAN SEBASTIÁN, SP, BRASIL

Rodrigo de Benedictis Delphino ${ }^{1}$

\begin{abstract}
Resumo: Esta pesquisa, realizada no município de São Sebastião, litoral norte do Estado de São Paulo teve como objetivo estudar o patrimônio natural e cultural. Ambos vêm sendo pressionados, de um lado pelo desenvolvimento econômico do porto, que vem crescendo e destacando-se na região, do outro, pela presença da Petrobrás que se encontra em franca expansão, e também do Turismo desenvolvido especialmente nas praias mais afastadas do centro do município. Destaca-se que o corpus da pesquisa foi construído por conveniência, a partir da indicação do primeiro depoente. Foi adotado o tipo de abordagem qualitativa, baseado nos depoimentos de quatro entrevistados, dois moradores e dois turistas de segunda residência que testemunharam transformações no município. O resultado da pesquisa foi que o patrimônio, tanto natural quanto cultural, está em risco, faltando propostas efetivas de preservação, assim como um planejamento urbanístico e turístico que se adéqüem as necessidades do município.
\end{abstract}

Palavras chave: Turismo. Patrimônio cultural. Patrimônio Natural. Planejamento. São Sebastião/SP.

Abstract: This research was held at São Sebastião Municipality, located at the northern part of São Paulo estate, Brazil. The aim was to assess natural and cultural heritage situation amidst three forces: economic development of port area, which is growing into a regional feature, Petrobras boom, and Tourism, mainly developed at

\footnotetext{
${ }^{1}$ Mestre em Hospitalidade pela Universidade Anhembi Morumbi. Professor do curso de PósGraduação Lato Sensu em Gestão Patrimonial e Ambiental em Turismo, assim como do curso de Tecnologia em Turismo do Cefet/RJ - Uned Nova Friburgo. E-mail: rodrigo.delphino@gmail.com
} 
ISSN: $1982-6125$

the seaside far from the center of the city. A qualitative approach was adopted as well as an intentional sample with four subjects, two permanent dwellers and two secondhome tourists, who witnessed the city transformation. The conclusion was that natural and cultural heritage are at risk because there are no heritage policies or urban and tourism planning which fit São Sebastião needs.

Keywords: Tourism. Natural Heritage. Cultural Heritage. Planning. São Sebastão (SP, Brazil).

Resumen: Esta investigación fue realizada en el municipio de San Sebastián, litoral norte del estado de San Pablo, Brasil y tuvo como objetivo estudiar el patrimonio natural y cultural, ambos presionados, de un lado, por el desarrollo económico del puerto que viene creciendo y destacándose en la región, por otro, debido a la presencia de la Petrobrás -que se encuentra en franca expansión-, y por el Turismo, especialmente en las playas más alejadas. Vale destacar que el corpus de la investigación fue construido por conveniencia, a partir de la indicación del primer entrevistado. La investigación fue cualitativa, entrevistándose cuatro personas, dos residentes permanentes y dos turistas de segunda residencia que fueron testigo de las transformaciones del municipio. El resultado fue que tanto el patrimonio natural como el cultural están corriendo riesgos, pues faltan políticas efectivas de preservación así como una planificación urbana y turística adecuadas a las necesidades del municipio.

Palabras clave: Turismo. Patrimonio Cultural. Patrimonio Natural. Planificación. San Sebastián (SP, Brasil)

\section{Introdução}

O município de São Sebastião, localizado no litoral norte de São Paulo é reconhecido pela qualidade de suas praias, sendo que muitas, por serem afastadas do centro do município, acabaram por contribuir para que condomínios surgissem na região, especificamente dentro de áreas de mata atlântica. ${ }^{2}$

Essa região do litoral paulista é reconhecida como uma área mais elitizada por ter praias com qualidade de água comparável a muitas praias do nordeste brasileiro. De acordo com coleta por amostragem da Companhia de Tecnologia de Saneamento Ambiental (CETESB), de 17/08/2009, mais de $80 \%$ das praias encontram-se aptas para banho. Isso contribui para que no período

\footnotetext{
${ }^{2}$ Este artigo integra a dissertação de Mestrado, Turismo e Patrimônio no Município de São Sebastião / SP, defendida em março de 2009, sob orientação da Profa. Dra. Sênia Bastos, na Universidade Anhembi Morumbi.
} 
ISSN: $1982-6125$

da alta temporada o fluxo em direção às mesmas seja intenso, causando vários engarrafamentos na orla marítima e contribuindo para o aumento da poluição em alguns locais.

As praias carecem de infra-estrutura, principalmente lixeiras para o descarte de resíduos. Num passado recente eram distribuídas sacolas plásticas aos visitantes, para acondicionar o lixo produzido, mas tal prática durou poucos verões. Segundo o Comitê dos Catadores de Materiais Recicláveis e Cooperativas do Vale do Paraíba e Litoral Norte, só não há um acúmulo maior de detritos nas areias, porque as associações de catadores mantêm um número grande de cooperados nas praias recolhendo todo material que possa ser reciclado, como latas de alumínio, garrafas pet, canudos plásticos e papel.

Segundo Sosa (1995, p. 10):

O turismo exige uma verdadeira transformação urbanística nas cidades aonde se exerce já que ela precisa dos mais completos serviços urbanos. Abastecimento de água, sistema de esgoto, iluminação e pavimentação de ruas, serviços de assistência sanitária, abastecimento de alimentos, etc. são aspectos fundamentais a serem adequadamente previstos devido ao aumento considerável da população na cidade nas épocas de temporada turística.

A reciclagem de lixo é bastante praticada no município, mas infelizmente isso acontece mais como alternativa de sobrevivência pela população desempregada, do que pela consciência ecológica.

De acordo com a Secretaria do Meio Ambiente de São Paulo, o litoral norte do Estado de São Paulo é provido de paisagens naturais exuberantes; as encostas da Serra do Mar cobertas pela mata atlântica, e a extensa faixa litorânea compõem esse cenário. Segundo a prefeitura de São Sebastião (www.saosebastiao.sp.gov.br):

Com quase 315 mil hectares, desde a divisa de São Paulo com o Rio de Janeiro, até o município de Itariri no sul do Estado, passando por toda a faixa litorânea, representa a maior porção contínua preservada de mata atlântica do Brasil. O Núcleo Caraguatatuba integra a rede de Unidades de Conservação, 
DELPHINO, Rodrigo de Benedictis. A gestão do desenvolvimento econômico conflitando com o patrimônio natural e cultural de São Sebastião. Revista Brasileira de Pesquisa em Turismo. v. 3, n. 2, p. 49-70, ago 2009.

ISSN: $1982-6125$

administrada pela Secretaria do Meio Ambiente, por meio do Instituto Florestal. Com o nome inicial de Reserva Florestal de Caraguatatuba, a área passou a ser um Núcleo do Parque Estadual da Serra do Mar em agosto de 1977, o primeiro do litoral norte e um marco na história da preservação da mata atlântica na região. Sua área de abrangência é de cerca de 88.000 hectares, incluindo os limites dos municípios de São Sebastião, Paraibuna, Salesópolis e Natividade da Serra.

A Serra do Mar foi tombada em 1985 pelo Condephaat ${ }^{3}$, sendo que cerca de $90 \%$ da área tombada é composta por parques, reservas e áreas de proteção especial e que em tese não podem ser derrubadas para a construção de qualquer edificação. A proteção se estende por vários municípios paulistas conforme se verifica no quadro 1 :

Município
Apiaí
Barra do Turvo
Biritiba Mirim
Cananéia
Capão Bonito
Caraguatatuba
Cubatão
Cunha
Eldorado Paulista
Embu-Guaçu
Guapiara
Ibiúna
Iguape
Ilhabela
Iporanga

Município
Itanhaém
Itariri
Jacupiranga
Juquiá
Juquitiba
Miracatu
Mogi das Cruzes
Monguagá
Natividade da Serra
Paraibuna
Pedro de Toledo
Peruíbe
Pilar do Sul
Praia Grande
Rio Grande da Serra

Município
Salesópolis
Santo André
Santos
São Bernardo do Campo
São Luiz do Paraitinga
São Miguel Arcanjo
São Paulo
São Sebastião
São Vicente
Sete Barras
Suzano
Tapiraí
Ubatuba

Quadro 1 - Relação de municípios abrangidos pelo tombamento da Serra do Mar. Fonte: http://www.tombamentodaserradomar.org.br/apresentacao.htm

\footnotetext{
${ }^{3}$ Decisão homologada pela Secretaria da Cultura e consubstanciada na Resolução SC no 40, de 6 de junho de 1985 publicada no Diário Oficial do Estado de São Paulo em 15/06/1985.

Fonte: http://www.tombamentodaserradomar.org.br
} 
ISSN: $1982-6125$

O órgão estadual responsável pela fiscalização ambiental é o Departamento Estadual de Proteção de Recursos Naturais (DPRN) ${ }^{4}$ que tem uma base técnica no município. Esse órgão é o responsável pela fiscalização dentro de áreas protegidas, competindo-Ihe a aprovação de solicitações de novas construções ou reformas nessas áreas.

As praias estão inseridas dentro dessa reserva e são protegidas por lei, sendo que algumas como, por exemplo, a de Barra do Sahy, Maresias, Toque Toque Grande e Toque Toque Pequeno ainda mantêm a simplicidade de suas construções originais.

Um dos grandes problemas que o município de São Sebastião enfrenta é a falta de espaços para a cidade crescer, em virtude das características do território: montanhas de um lado e o mar do outro.

É notório que com tal dificuldade, os espaços visados concentram-se, no centro do município. Pela falta de destinação oficial os terrenos dos imóveis históricos acabam por ser o alvo preferido para a construção de novos empreendimentos, sejam comerciais, residenciais ou industriais.

\section{O destino do lixo}

Com a falta de espaço para crescer, agravou-se o problema da correta destinação do lixo. Por ser uma cidade turística, na alta temporada a produção do lixo muitas vezes é multiplicada por quatro, trazendo implicações sérias para o município.

Segundo matéria do jornal Folha de São Paulo (30/11/2008):

\footnotetext{
${ }^{4}$ Tem por atribuição legal executar o licenciamento e a fiscalização do uso dos recursos naturais no Estado de São Paulo, visando disciplinar a implantação das atividades e empreendimentos que impliquem supressão, exploração e manejo de vegetação nativa e intervenções em áreas de preservação permanente ou especialmente protegida, na conformidade do disposto nas legislações vigentes, especialmente o Artigo $2^{\circ}$ da Lei Federal 4.771/65 (SECRETARIA DE MEIO AMBIENTE DE SÃO PAULO, 2004, p.4).
} 
Em outubro de 2008 a CETESB interditou o único aterro ainda em funcionamento no litoral norte paulista, localizado em Ubatuba. A cidade de São Sebastião optou por exportar seu lixo para o município de Tremembé, localizado no interior paulista, arcando com os custos do transporte e destinação do lixo visando minimizar tal questão.

Caraguatatuba, Ilhabela, Ubatuba e São Sebastião produzem cinco mil toneladas de detritos, o que resulta uma média de mil duzentos e cinqüenta toneladas mensais para cada cidade, isso na baixa temporada. $\mathrm{Na}$ alta temporada, cada uma produz mensalmente mais de cinco mil toneladas em média.

O problema desse processo é que o lixo é exportado via transporte rodoviário e o custo tende a se ampliar cada vez mais, corroendo as finanças desses municípios. De São Sebastião até a cidade de Tremembé são 210 km, percorridos de caminhão, o custo para cada cidade entre coleta e destinação do lixo beira os duzentos reais (cem dólares americanos) por tonelada.

O Secretário Estadual de Meio Ambiente Francisco Graziano, em matéria publicada no Caderno Cotidiano do jornal Folha de São Paulo (30/11/2008) afirmou que nenhum novo aterro sanitário será aberto em qualquer dessas cidades sem que haja licença ambiental: "Os locais que foram fechados não vão abrir mais. E vamos ser rigorosos com os projetos [de aterros], quaisquer que sejam".

Segundo artigo de Credendio (2008) publicado no Caderno Cotidiano do Jornal Folha de São Paulo o volume de lixo gerado é tão grande na alta temporada, que o trecho entre as praias de Juqueí e Barra do Una correspondem ao mesmo volume que toda a cidade gera na baixa estação. Bergamo (2009), em matéria da Revista Veja São Paulo, destaca outro problema: o lixo transportado pela estrada resulta em mais poluição, visto que o chorume 5 "vaza" próximo às áreas de preservação no percurso rodoviário.

\footnotetext{
${ }^{5}$ Líquido resultante da decomposição dos dejetos.
} 
O município de São Sebastião vem tentando reduzir o lixo encaminhado ao aterro, com campanhas de reciclagem de lixo, o que proporciona redução do valor pago e ainda contribuem com o meio ambiente. Além disso, a campanha também consegue gerar empregos para a comunidade caiçara.

\section{Os condomínios}

A partir da década de 1950 o ambiente natural do litoral norte paulista, formado pelos municípios de Caraguatatuba, Ubatuba, Ilhabela, Bertioga e São Sebastião, começou a sofrer as conseqüências de uma ocupação desenfreada, decorrente, principalmente, da abertura de rodovias que deram acesso à região (CARVALHO, 2001). Tal fator propiciou a expansão do Turismo nesses municípios, pois o acesso que antes era difícil (no caso de Caraguatatuba só era possível pelo mar) foi facilitado, resultando no incremento da visitação da região.

O traçado da BR-101, também conhecida como Rio-Santos, margeia o mar e divide algumas vilas ao meio, trazendo a urbanização e a construção de condomínios em redutos caiçaras remanescentes. Embora tenha sido construída na década de 1960, pelo Governo Federal, só foi pavimentada no período entre 1979 e 1985 (LUCHIARI, 2002, p. 154). Nem sempre é possível avistar o mar da estrada, apesar de sua proximidade, em virtude da presença de edificações construídas à beira mar que dificultam a visão. Em alguns locais a estrada acabou por dividir ao meio as comunidades caiçaras provocando acidentes com transeuntes, principalmente crianças e animais que perambulam pela pista, enquanto os automóveis passam em alta velocidade.

Além do Turismo, a partir da metade do século XX, com a implantação do Porto de São Sebastião e da Petróleo Brasileiro S. A (Petrobrás) observa-se um novo surto econômico, que levou a uma mudança em relação ao uso da terra e 
ISSN: $1982-6125$

do trabalho. De acordo com Domschke (1998, p. 36) "toda a área que era ocupada por roças foi desapropriada para dar lugar às empresas, e a população foi obrigada a ir para lugares mais distantes."

Carvalho (2001, p. 4) acrescenta a esse universo os efeitos advindos da atividade turística:

O Turismo como vetor de desenvolvimento local, provocou a venda de posses de terra e um impacto cultural, que culminou com a debilitação das instituições da cultura caiçara.

Para Luchiari (2002), do ponto de vista dos caiçaras, é nítida a percepção de transformação da paisagem natural, pois seu próprio modo de vida sempre esteve associado aos elementos naturais da paisagem, tanto nas atividades econômicas como a caça e a pesca, como nas atividades sociais, como as festas e as crenças.

A população que vivia na costa vendeu suas terras e migrou para o sertão, que corresponde às áreas próximas das montanhas, longe do mar e segmentada pela estrada iniciando-se, assim, a construção de casas e condomínios para turistas de veraneio em áreas que pertenciam à população local.

A ambição pelas terras para expandir o Turismo contribuiu para expulsar do litoral antigos pescadores. Subsistindo da pesca, esses moradores passaram a viver junto à mata, o chamado sertão, perdendo a facilidade de acesso ao mar (DOMINGUES; TRENTIN, 2006, p. 292).

É importante que sejam satisfeitas as necessidades dos turistas, assim como dos moradores e que aja interatividade entre ambos, ou seja, o morador não pode simplesmente ser expulso de suas terras (SCHMITT, 2006). É preciso conciliar o interesse de ambos, para que as relações sejam o mais harmoniosa possível.

De acordo com Beni (2003, p. 112):

O turismo é um fenômeno eminentemente social e tem como elementos os turistas, os trabalhadores e o grupo estável 
receptor composto pela comunidade local. O turismo pode ser empregado para fins de desenvolvimento nacional e regional, nos campos social, cultural e no político. As atividades originadas fazem gerar efeitos sobre o meio ambiente, e desenvolvimento do turismo está bastante relacionado coma ordenação do território.

Os condomínios construídos geram muitos empregos, principalmente de caseiros, jardineiros e no comércio instalado nas praias, nos centros de compras locais, graças ao fato do município de São Sebastião ter seu potencial turístico associado ao sol e à praia. Com a preservação do patrimônio cultural a cidade pode buscar alternativas e investir em outros segmentos, como o Turismo cultural, diminuindo a dependência de apenas um tipo de turista, além de evitar ou minimizar a perda da história local (PORTUGUEZ, 2001).

As melhores praias do município são afastadas do centro e são, em sua maioria, redutos de condomínios de médio e alto padrão. Devido à distância, qualidade da estrada e até mesmo um provável desconhecimento, os turistas pouco freqüentam esse espaço histórico no centro do município. Isso faz com que muitos dos problemas relatados nessa pesquisa não sejam percebidos por esses moradores temporários, muitos só relembram que existe uma base da Petrobrás, quando ocorre algum vazamento de óleo em alguma praia, sendo que no Rio Guaecá, na praia de mesmo nome, isto costuma ocorrer com alguma freqüência. Já nas outras praias mais afastadas dificilmente ocorre algum desastre com regularidade suficiente para comprometer a qualidade de sua água e que cause a mortandade de peixes ou de outros seres vivos.

\begin{tabular}{|c|c|c|c|}
\hline Identificação do bairro & Distância do centro & Identificação do bairro & Distância do centro \\
\hline Enseada & $12 \mathrm{~km}$ & Toque Toque Pequeno & $21 \mathrm{~km}$ \\
\hline Cigarras & $9,5 \mathrm{~km}$ & Santiago & $22 \mathrm{~km}$ \\
\hline Arrastão & $3,5 \mathrm{~km}$ & Maresias & $30 \mathrm{~km}$ \\
\hline Guaecá & $12 \mathrm{~km}$ & Boiçucanga & $36 \mathrm{~km}$ \\
\hline Barequeçaba & $3,5 \mathrm{~km}$ & Camburi & $40 \mathrm{~km}$ \\
\hline
\end{tabular}

Quadro 2 - Distância dos bairros em relação ao centro de São Sebastião Fonte: www.guiadesaosebastiao.com.br 
De acordo com o quadro 2, as praias distam pelo menos $3 \mathrm{~km}$ do centro da cidade, sendo que algumas chegam a estar a mais de $40 \mathrm{~km}$, inviabilizando a ida com maior freqüência. Outro dado importante é que o acesso de Caraguatatuba até São Sebastião se dá por uma estrada com sinalização e asfalto já deteriorados, enquanto que o acesso do centro de São Sebastião em direção às praias sentido Bertioga tem excelente pavimento e sinalização. Trata-se também da direção onde estão localizados os condomínios de luxo, bairros que concentram os investimentos em melhoria de infra-estrutura, já em outros que não tem praias, nem condomínios abastados, a realidade é um pouco diferente.

Luchiari (2002, p. 149) afirma que:

[...] os condomínios fechados representam um tipo de segregação socioespacial que permite às classes médias e elites sociais detentoras de recursos para pagar pela privatização de áreas valorizadas, distantes e isoladas dos problemas urbanos.

No caso do município de São Sebastião cabe destacar que a expansão do Porto e da Petrobrás pouco afeta os redutos turísticos localizados nos bairros mais distantes do centro da cidade.

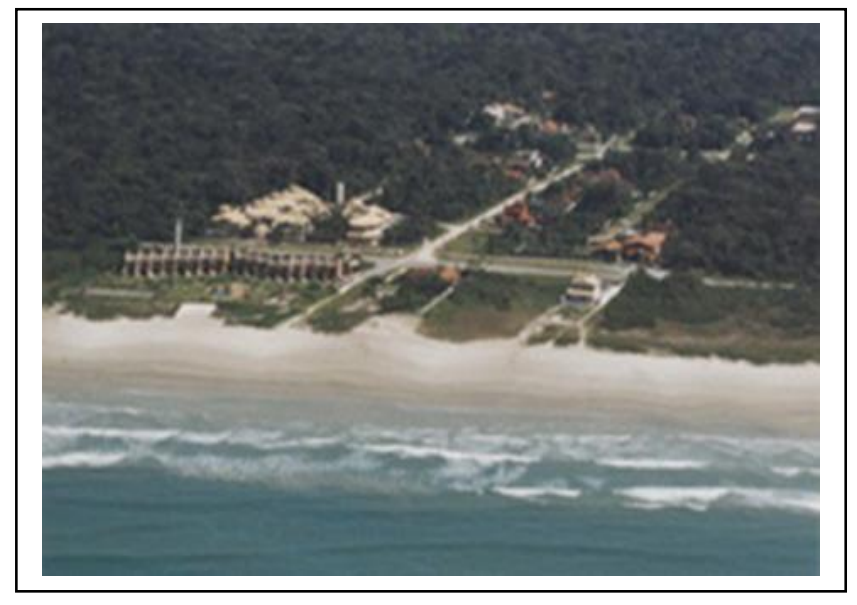

Figura 1 - Condomínio à beira mar

Fonte: http://www.consurb.com.br/img/miniatura/litoral/t_boraceia_g.jpg 
Muitos desses empreendimentos imobiliários de uso ocasional são localizados à beira mar, com muros que impedem o acesso e a visão das praias contribuindo para que os moradores fiquem cada vez mais afastados dos locais de grande badalação e de suas belezas naturais. Luchiari (2002, p. 142-3) mostra claramente que a ocupação desses espaços por turistas tem como motivação o meio natural, que é considerado um refúgio para suas residências secundárias, e que a relação do caiçara com o local também se torna secundária, pois a paisagem está sendo transformada, a cultura está sendo espoliada. Isso significa que tanto a paisagem quanto as comunidades tipicamente caiçaras estão sendo consumidas pelo Turismo.

A construção de novos condomínios está contribuindo para a derrubada da cobertura vegetal e os próprios turistas já começam a perceber a gravidade do problema. Além disso, algumas decisões que são tomadas em prol da indústria da construção civil, sem respaldo técnico, afetam a qualidade de vida, comprometendo a proteção a flora local.

Conforme Sosa (1995, p. 10):

Quando bem organizado, o planejamento do traçado urbano, das normas construtivas, regulamento do uso do solo, as cidades se transformam em centros turísticos com características peculiares contribuindo para acrescentar atrativos aos já existentes no lugar.

Na figura 1 é possível perceber que nem sempre isso acontece, pois os condomínios instalados em reservas de mata atlântica, teoricamente protegidas, criam praias exclusivas a seus moradores, impedindo que os demais habitantes do bairro tenham acesso livre ao patrimônio natural, que é público. Como espaço de disputa econômica, política e simbólica, o patrimônio está sob a ação do setor privado, do Estado e dos movimentos sociais. O setor privado leva à exploração indiscriminada do ambiente natural e urbano, a expansão voraz da especulação imobiliária em detrimento dos bens culturais e do interesse majoritário (GARCÍA CANCLINI, 1999). Sosa (1995) chama a 
ISSN: 1982-6125

atenção para a alta procura por apartamentos e casas de aluguel como meio de hospedagem que vem crescendo anualmente e que contribui ainda mais para a expansão de condomínios a beira mar.

Barretto (2004) discorre sobre o fato de que o Turismo remete ao colonialismo cultural e à xenofobia, pois a exclusão social que essa atividade propicia é voraz ao repelir cada vez mais a população de seus redutos naturais e culturais e também traz diversos problemas sazonais. Conforme Barretto (2004, p.143) "a relação entre visitantes e visitados é de competição por produtos escassos e que acabam causando aumento de preço especialmente para o morador".

Por sua vez Cruz (2001) questiona se existem áreas onde o Turismo não pode se expandir, ou seja, locais onde a atividade turística pode ser impedida de participar e ou desenvolver-se, pois segundo a autora, Turismo significa apropriação de espaços, e não há limites para essa prática. A dinâmica da produção de territórios turísticos, ou seja, da apropriação dos espaços pela prática social do Turismo, comporta o abandono parcial de outros lugares, pois o que valoriza um local são os modismos.

Algumas praias são badaladas graças aos condomínios que foram construídos ao seu redor, que propiciaram, inclusive, pela distância em relação ao centro do Município, a implantação de um centro comercial em quase todas as praias, contribuindo também para a formação de locais onde o descaso de alguns turistas em relação à população local fica bastante evidente.

\section{O Porto e a atividade econômica}

O Porto está localizado a 200 km da cidade de São Paulo e desempenha importante papel no desenvolvimento de São Sebastião. Em uma época em que os meios de comunicação eram escassos, o porto representava o elo entre o centro administrativo da colônia, a metrópole, as vilas e os povoados do 
ISSN: $1982-6125$

interior. Foi escoadouro de produtos como: açúcar e ouro e receptor de importações como ferragens, tecido e artigos de luxo.

Entre 1934 e 1942 foi construído o atual porto comercial e com o crescente movimento do Porto de Santos, o Governo do Estado requereu à União a concessão do Porto de São Sebastião, visando a sua exploração. Através do Decreto-Lei no 63, de 15/05/1969, foi criada a Companhia Docas de São Sebastião (CDSS), para administrá-lo, encontra-se vinculada à Secretaria de Estado dos Transportes de São Paulo (http:// www.dersa.sp.gov.br). Em virtude de sua configuração natural, o canal de São Sebastião é considerado a terceira melhor região portuária do mundo. Isso faz das condições de calado (profundidade) e abrigo à navegação as mais confortáveis e seguras. Devido à expansão da economia paulista e localização privilegiada, este terminal portuário começou a se destacar e ter sua importância econômica valorizada. Porém, para poder atender a crescente demanda, é necessário investir na ampliação do seu espaço e também no calado por onde passam e atracam os navios.

Segundo a Companhia Docas, o movimento gira em torno de $500 \mathrm{mil}$ toneladas/ano. A meta era dobrar esse volume para um milhão de toneladas, até dezembro de 2008. A área total do terminal é de 2,9 milhões de metros quadrados, ocupando $70 \%$ da região central da cidade. Na figura 2 é possível perceber que o centro histórico localiza-se de frente para a praia de São Sebastião, bastante próximo dessa instalação portuária.

O governo do Estado tem um projeto em conjunto com a Petrobrás para ampliação do local cujos investimentos demandados giram em torno de dois bilhões de reais. A idéia é desafogar o Porto de Santos e aumentar o fluxo do terminal de cargas de São Sebastião. Foi idealizado o plano integrado portocidade, que envolve a readequação da infra-estrutura portuária e inclui a mudança do atracamento da balsa que liga os municípios de São Sebastião a Ilhabela. Segundo Alencar (2008) em artigo publicado na Revista Litoral Norte, 
ISSN: $1982-6125$

dentro dessa expansão portuária está prevista também a atração de navios de cruzeiro, concorrendo com Ilhabela pelos turistas que desembarcam desses navios.

Para esta ampliação será incorporada parte remanescente da baía do Araçá próximo da balsa (figura 2), espaço que enfrenta, há alguns anos, um processo de assoreamento ${ }^{6}$ que tem alterado as características da baía há algum tempo, entre outros motivos, porque tal problema decorre, em grande parte, de material contaminado que a ela vem sendo despejado pelos navios que se dirigem ao porto.

Um dos maiores entraves para a sua expansão é sua proximidade ao centro do município e, conseqüentemente seu centro histórico, fazendo com que qualquer tipo de ampliação afete, mesmo que indiretamente, o seu patrimônio cultural seja ele tombado ou não.

Segundo Bussinger (Revista Litoral Norte, julho de 2008), presidente da CDSS que administra o porto:

[...] Empreendimentos humanos normalmente produzem impactos, principalmente quando se trata da implantação de infra-estruturas. Alias, é justamente para isso que eles são concebidos, projetados e postos em funcionamento. São impactos ambientais, mas, também, impactos sociais e impactos econômicos. São impactos negativos, mas, também, impactos positivos: Difícil imaginar-se empreendimentos só com impactos negativos!

O presidente da CDSS refere-se à destruição de edificações históricas que estavam justamente no terreno a ser utilizado na ampliação do porto, assim como ao aterramento do mangue, que é o berço de peixes e moluscos que simplesmente podem desaparecer. Segundo o caderno Cotidiano do Jornal Folha de São Paulo7, a área a ser aterrada tem $500 \mathrm{mil} \mathrm{m}^{2}$. Área de rica biodiversidade é utilizada freqüentemente como laboratório aberto pelo Centro de Biologia Marinha (CEBIMAR) da Universidade de São Paulo (USP), localizada

\footnotetext{
${ }^{6}$ Perda de profundidade devido à sedimentação.

${ }^{7}$ http://www1.folha.uol.com.br/fsp/cotidian/ff1203200829.htm
} 
ISSN: 1982-6125

no município. No site da USP existem mais de cem dissertações a respeito do meio ambiente local, pois é nos manguezais que diversas espécies se alimentam e buscam proteção. "O mangue faz parte do ciclo de vida de peixes, crustáceos e moluscos. Tem uma cadeia biológica enorme ali", afirma o ambientalista e advogado Eduardo Hipólito do Rego, suplente do Conselho Estadual do Meio Ambiente (Consema), em matéria publicada no site portal do litoral norte (http://www.portaldolitoral.com.br).

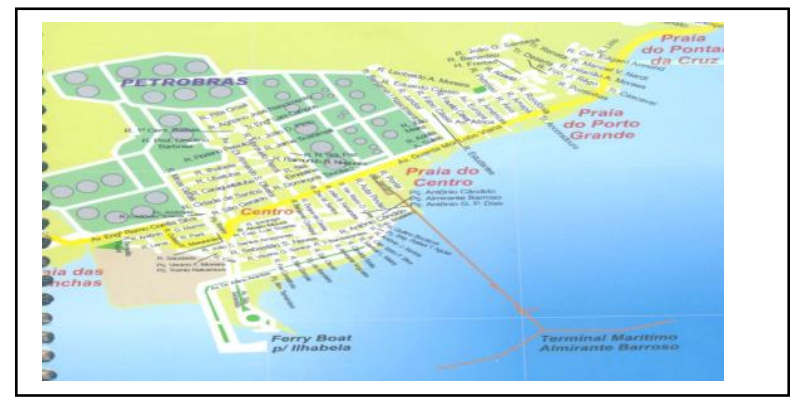

Figura 2 -Vista aérea da cidade

Fonte: www.guiaviagemturismo.com.br

\section{A Petrobrás}

Em 1961, começaram as obras do Terminal Marítimo Almirante Barroso (Tebar), da Petrobrás, que perduraram até 1969. Seus dutos ligam São Sebastião a Santos, Cubatão, Paulínia e Capuava. Em 1968, um petroleiro norueguês realizou a primeira operação de atracação no píer, inaugurando o terminal com o bombeamento de petróleo cru trazido do Iraque. Hoje é administrado pela Petrobrás Transportes S/A (Transpetro). O terminal é responsável por $50 \%$ da movimentação de petróleo do país, com 39 tanques com capacidade para armazenamento de 12 milhões de barris. A movimentação no terminal gira em torno de 38,9 milhões de metros cúbicos de petróleo e derivados. $35 \%$ do volume é importado, o que possibilita um aumento na arrecadação de Imposto Sobre Circulação de Mercadorias (ICMS) do Município, sendo que cerca de $50 \%$ do orçamento da cidade vem das 
operações de entrada e saída de petróleo no Tebar (JORNAL VALE PARAIBANO, 10/07/2007) que acaba tendo um peso considerável nas contas da Prefeitura e, conseqüentemente, na aprovação de projetos da estatal.

Atualmente, a empresa está implantando no litoral norte, o Projeto Mexilhão, que servirá para produção de gás natural. Para tanto está construindo um gasoduto de ligação com o continente, de aproximadamente 143 km de extensão entre a Plataforma e a Unidade de Tratamento de Gás (UTG) Monteiro Lobato, em Caraguatatuba. O gás natural será transportado por gasoduto até uma estação em Taubaté, interligado ao gasoduto Campinas/Rio, e o condensado de gás natural, conhecido como gasolina natural será enviado até o Tebar, em São Sebastião.

O centro da cidade e, conseqüentemente, seu centro cultural, encontrase espremido entre os tanques de petróleo e o mar. A expansão, principalmente da Petrobrás e do porto, em nada contribui para a criação de espaços de convivência na região; na verdade, os mesmos estão sendo eliminados.

De acordo com Grinover (2007, p. 31) "faz parte da cidadania a incorporação do território como espaço não só de habitação, mas também de vivência e convivência". Essa perda de espaços de sociabilidade deixa clara a priorização da atividade econômica em detrimento da função residencial ou de lazer, resultando na transferência dos moradores para outras regiões. E uma empresa de petróleo com seus tonéis que descaracterizam totalmente a paisagem, assim como representam um grande risco para a cidade, em caso de algum acidente, é que as está expulsando em nome do progresso e do crescimento econômico. Outro exemplo de como esse crescimento afeta a cidade e conseqüentemente as praias, é a futura presença dos dutos que ligarão o Projeto Mexilhão em Caraguatatuba ao Terminal Almirante Barroso, para posterior exportação. 
DELPHINO, Rodrigo de Benedictis. A gestão do desenvolvimento econômico conflitando com o patrimônio natural e cultural de São Sebastião. Revista Brasileira de Pesquisa em Turismo. v. 3, n. 2, p. 49-70, ago 2009.

ISSN: $1982-6125$

Embora a empresa tenha seu grau de importância econômica local e regional, necessita ser ética e mostrar que se preocupa com as pessoas que moram ao redor de suas instalações. É preciso valorizar seu entorno, demonstrando para os moradores que a empresa se preocupa com o meio ambiente e que segue todas as normas adequadamente.

Além disso, o mangue ${ }^{8}$ (constitui um ecossistema produtivo, complexo e rico, onde os caranguejos vivem e se reproduzem) localizado na zona costeira não deve ser ameaçado visto que é protegido pela Lei Federal 4.771/1965, que determina que o ecossistema configure-se como Área de Preservação Permanente. Ainda assim, a própria prefeitura local autorizou o aterramento do mangue.

Conforme informações da Sectur, a prefeitura aterrou há quinze anos atrás um pedaço do mangue que hoje é um depósito a céu aberto, conforme se observa na figura 3, espaço este que em a prefeitura guarda os pontos destinados às paradas de ônibus municipais. Além disso, o mangue sofre com o excesso de poluição, principalmente por se localizar perto da balsa e não haver um controle eficaz, nem latões de lixo por perto buscando reduzir tal situação.

80 art. 225, $\S 40$ da Constituição Federal brasileira considera a Zona Costeira como "Patrimônio nacional", devendo ser utilizada observando a preservação do meio ambiente. $O$ art. 196 da Constituição do Estado de São Paulo também a protege, bem como o Complexo Estuário Lagunar entre Iguape e Cananéia como espaços territoriais especialmente protegidos, podendo ser utilizado apenas com autorização, mas sempre observando a preservação do meio ambiente, bem como em seu art. 197, I considera expressamente os manguezais áreas de proteção permanente. Por sua vez a Lei 7661 , de $16 / 05 / 88$, que instituiu o Plano Nacional de Gerenciamento Costeiro (PNGC) definiu em seu art. 20, parágrafo único, a Zona Costeira como "o espaço geográfico de interação do ar, do mar e da terra, incluindo seus recursos renováveis ou não, abrangendo uma faixa marítima e outra terrestre, que serão definidas pelo Plano", e em seu art. 30, I, dá prioridade à conservação e proteção, em caso de zoneamento, entre outros, aos manguezais, prevendo, inclusive, sanções como interdição, embargos e demolição (art. $6^{\circ}$ ), além das penalidades do art. 14 da Lei 6.938/81, que instituiu a Política Nacional do Meio Ambiente. 


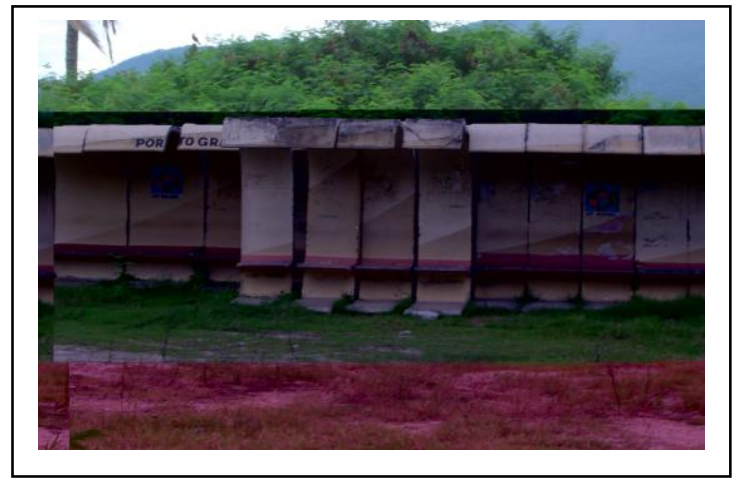

Figura 3 - Depósito à céu aberto construído em área aterrada de mangue comporta diversos pontos de ônibus

Fonte: Delphino (2009)

A cidade tem de crescer minimizando ao máximo os danos ao meio ambiente ou ao patrimônio cultural, evitando que sejam destruídos ou descaracterizados em prol do progresso tecnológico e do desenvolvimento econômico. Mas também tem que dar condições para que a população possa viver dignamente, respeitando seu espaço, sua história, sua memória para proporcionar um desenvolvimento contínuo e duradouro, onde os turistas possam aliar seu descanso com o conhecimento de outras culturas. A preservação é a melhor maneira para que projetos de renovação e revitalização urbana e natural produzam respostas de interesse público (MENEZES, 1992, p. 194).

A cidade não tem de se desfazer do porto ou se incomodar com a Petrobrás, é possível uma coexistência desde que sustentável, onde um não depende da destruição do outro para progredir garantindo, assim, um crescimento de longo prazo para todo o município.

De acordo com Schmitt (2006, p. 25):

A atividade turística é causadora de impactos, tanto socioeconômicos como ambientais [...] O sistema turístico é um sistema aberto formado pela oferta e suas interfaces com a demanda. A atividade turística, enquanto sistema relaciona-se com os ambientes sociais, culturais, políticos, econômicos e com os ecossistemas. 
São necessárias políticas específicas que regulem a atividade e seus impactos, tentando com isso minimizar ao máximo possíveis problemas tanto com o patrimônio natural e cultural quanto com os moradores locais.

\section{Considerações Finais}

O município cresceu bastante, principalmente na região próxima ao centro da cidade. A Petrobrás e o Porto acabam por exercer uma forte pressão ao patrimônio natural e cultural da cidade. A falta de espaços praticamente obriga que as empresas mirem o patrimônio, como alternativa viável para expandir seus negócios.

Os condomínios, e seus moradores, em sua maioria distantes do centro do município acabam por não sentir essa pressão e acabam por viver como se tais problemas não existissem. Cada praia acabou por formar seu próprio centro, com todas as comodidades possíveis, muitas vezes contribuindo para que o turista ou morador pouco vá ao centro comercial do município.

Pela falta de espaços no centro, a especulação imobiliária acaba por contribuir para a descaracterização ou eliminação de bens históricos, pois muitos proprietários não têm condições econômicas ou interesse em manter o imóvel original. Espaços que antes tinham uso residencial viraram templos de consumo: lojas, restaurantes, sorveterias etc.

Segundo Menezes (1992, p. 96):

A impecável lógica do espaço-mercadoria provoca a autofagia e a expropriação do habitante que cada vez mais vai morar mais longe de onde nasceu, cresceu e viveu.

Como as distâncias são grandes e a qualidade da estrada também não ajuda, o turista pouco freqüenta o centro do município, preferindo passear apenas pelos arredores de onde está hospedado. Isso contribui para que cada 
ISSN: $1982-6125$

vez mais o patrimônio cultural do centro seja esquecido e também para que muitos restaurantes tenham fechado as portas. Hoje, para ir a um bom restaurante é preciso pegar a estrada em direção a Caraguatatuba, pois alguns bons estabelecimentos gastronômicos preferiram se instalar longe do centro, que passa uma imagem de triste abandono. Há dez anos atrás, o centro vivia lotado de turistas, era difícil arrumar um local para estacionar o carro, situação diferente da de hoje, onde mesmo na alta temporada, é fácil encontrar vaga nesses locais.

Esse trânsito foi transferido para os bairros distantes, redutos de condomínios e cada vez mais procurados por turistas eventuais e de segunda residência, interessados nas poucas belezas naturais ainda intocadas da região, mas também desfamiliarizados com os problemas enfrentados pelo centro cultural de São Sebastião.

O desenvolvimento econômico é importante, mas precisa ser incentivado sustentavelmente, ou seja, de forma planejada, preservando o patrimônio existente, seja ele natural ou cultural sem destruição, visando que as gerações futuras não percam sua identidade, sua memória. A expansão industrial é importante, mas não se pode permitir que em seu nome, empresas como principalmente, a Petrobrás, venham poluir e, em algumas situações, provocar danos irreparáveis à fauna e a flora do município. O desenvolvimento planejado traz segurança não só aos turistas, mas também aos moradores. Esperamos que este nosso trabalho seja um alerta sobre a necessidade constante de vigilância sobre o patrimônio cultural e natural e uma bandeira a ser desfraldada pelos políticos locais. 
ISSN: 1982-6125

\section{Referências}

ALENCAR, N. Porto de São Sebastião: Proposta de expansão após uma vida de expectativas. Revista Litoral Norte Magazine. $\mathrm{n}^{0} 11$, ano II, junho a julho de 2008.

BARRETTO, Margarita. Relações entre visitantes e visitados: um retrospecto dos estudos socioantropológicos. Turismo em Análise, v.15, n. 2. São Paulo: Aleph, p. 134-149, 2004.

BENI, Mario Carlos. Análise estrutural do turismo. São Paulo: Senac, 2003.

BERGAMO, Giuliana. Litoral Norte. O nosso espião do espaço. Revista Veja São Paulo, 08/04/2009.

CARVALHO, Heidi Cristina Buzato. O artesanato de caixeta em São Sebastião. 2001. Dissertação (Mestrado em Ciências Florestais), Piracicaba, Escola Superior de Agricultura Luiz de Queiroz (ESALQ), Universidade de São Paulo, 2001.

CREDENDIO, José Ernesto, Caderno Cotidiano, Jornal Folha de São Paulo, $30 / 11 / 2008$.

CRUZ, Rita de Cássia Ariza da. Introdução à geografia do Turismo. São Paulo: Roca, 2001.

DELPHINO, Rodrigo De Benedictis. Turismo e patrimônio no município de São Sebastião / SP. 2009. Dissertação (Mestrado em Hospitalidade). São Paulo: Universidade Anhembi Morumbi, 2009.

DOMSCHKE, Vera Lucia. São Sebastião: Proposta de Renovação Urbana. 1998. Dissertação (Mestrado em Arquitetura), São Paulo: Faculdade de arquitetura e Urbanismo, Universidade de São Paulo, 1998.

GARCIA CANCLINI, Néstor. Los usos sociales del patrimonio cultural. In: Aguilar Criado, Encarnación. Patrimônio Etnológico. Nuevas Perspectivas de estúdio. Consejeria de Cultura. Junta de Andalucia. p. 16-33, 1999.

GRINOVER, Lucio. A Hospitalidade, a Cidade e o Turismo. São Paulo: Aleph, 2007.

LUCHIARI, Maria Tereza D. P. Urbanização turística: um novo nexo entre lugar e o mundo. In: SERRANO, Célia; BRUHNS, Heloísa; LUCHIARI, Maria Tereza D. 
DELPHINO, Rodrigo de Benedictis. A gestão do desenvolvimento econômico conflitando com o patrimônio natural e cultural de São Sebastião. Revista Brasileira de Pesquisa em Turismo. v. 3, n. 2, p. 49-70, ago 2009.

ISSN: 1982-6125

P (org.). Olhares contemporâneos sobre o turismo. Campinas: Papirus, 2002, p. $105-130$.

MENEZES, Ulpiano T. Bezerra. Os usos culturais da cultura. Contribuição para uma abordagem crítica das práticas e políticas culturais. In: YAZIGI, Eduardo e outros. Turismo, espaço, paisagem e cultura. São Paulo: Hucitec, 1996.

PORTUGUEZ, Anderson Pereira. Consumo e espaço. São Paulo: Roca, 2001.

SCHMITT, Valentina Gomes Haensel. Comportamento do turista estrangeiro em Florianópolis. 2006. Dissertação (Mestrado em Administração). Florianópolis: Universidade Federal de Santa Catarina, 2006.

SOSA, María Mercedes Sosa de. Adequação da habitação de praia para o turista argentino em Florianópolis - Santa Catarina. 1995. Dissertação (Mestrado em Engenharia de Produção). Florianópolis: Universidade Federal de Santa Catarina, 1995.

TRENTIN, Fabia; DOMINGUES, Viviane. Pesca Artesanal no litoral paulista: a cultura caiçara valorizada pelo turismo. In: TREVIZAN, Salvador D. P. (org). Comunidades Sustentáveis, a partir do Turismo com base local. Ilhéus. Editus, 2006.

\section{Sítios da Internet}

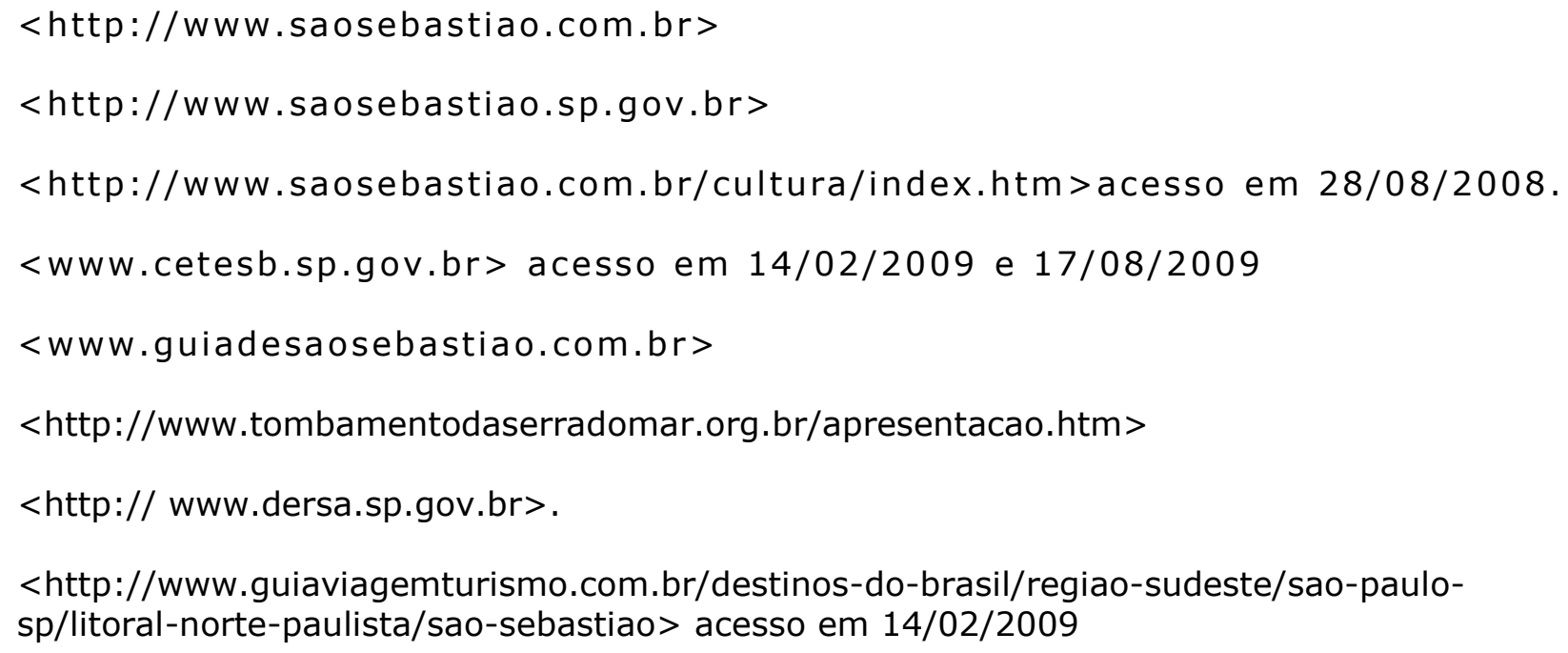

Recebido em julho de 2009.

Aprovado em agosto de 2009. 